\title{
TERRAS INDÍGENAS NA LEGISLAÇÃO COLONIAL
}

\author{
Beatriz Perrone-Moisés \\ Professora Doutora do Departamento de Antropologia da \\ Faculdade de Filosofia, Letras e Ciências Humanas da \\ Universidade de São Paulo
}

Resumo:

Este artigo analisa algumas questões envolvidas no reconhecimento legal dos direitos territoriais dos índios, a partir da legislação indigenista colonial. Busca refletir especialmente acerca do modo como o avanço da colonização significou, na prática, a perda por parte dos índios dos direitos às suas terras, sem que estes jamais tenham sido negados pela legislação.

Abstract:

This article analizes some of the questions implied in the legal recognition of native land rights in Colonial Brazil. It considers specially how the advance of colonization meant, in practical terms, the loss, by the Indians, of their land rights, which were never denied by the laws.

Unitermos: direitos territoriais; índios; período colonial; legislação indigenista.

O debate jurídico acerca dos direitos territoriais no Novo Mundo constitui parte importante do conhecido movimento de reflexão gerado, na Europa, pela descoberta e colonização da América. Já no século XVI, questiona-se a legitimidade da presença européia no continente americano e de seu domínio sobre aquelas terras. Embora o Papa tivesse dividido as novas descobertas entre Portugal e Espanha, partilha consagrada no Tratado de Tordesilhas, posições teológicojurídicas já colocavam em dúvida seu direito de dispor daquelas terras, afirmando que sua autoridade se restringia ao plano espiritual. A idéia de que ao Papa caberia apenas o domínio espiritual não era, aliás, nova: já se en€ontrava, por exemplo, em São Tomás de Aquino, desde o século XIII. De modo que a questão embutida na famosa ironia do rei francês Francisco I que, diante das reivindicações territoriais de Portugal relativas ao Brasil, pedia para ver a cláusula do "Testamento de Adão" que o excluíra da partilha do mundo, era tema central dos debates intensos que ocorriam 
nos países beneficiados por tal partilha. De fato, reconheceu-se logo que, à diferença das terras dos infiéis, essas terras que "desconheciam a palavra de Deus" habitadas por gentios, não podiam ser reclamadas pela cristandade. Se os mouros, por serem infiéis, não tinham direitos sobre as terras que ocupavam, e estas lhes podiam, conseqüentemente, ser justamente tomadas por cristãos, era outro o caso dos povos pagãos das Américas.

A distinção entre infiéis e gentios, fundamental no que diz respeito aos direitos de indigenas e europeus no Novo Mundo, fora introduzida nos debates teológico-jurídicos no início do século XVI, pelo cardeal Cayetano, superior da ordem dos dominicanos em Roma, em comentário ao pensamento de São Tomás de Aquino. Mas foi Francisco Vitória, famoso jurista da escolástica espanhola em cuja obra dedicada aos problemas éticos e jurídicos da conquista ${ }^{1}$ o moderno Direito Internacional reconhece uma de suas primeiras formulações, quem com maior autoridade afirmou o Direito Natural dos povos indigenas da América de constituir sociedades políticas independentes. Isso significava que os gentios americanos eram os legítimos proprietários de todos os seus bens, inclusive e, principalmente, de suas terras, e dispunham de liberdade para exercer seus direitos naturais. ${ }^{2}$ Conseqüentemente, nada no novo continente podia ser justamente reivindicado pelos europeus. $^{3}$

A legislação portuguesa para a Colônia brasileira ${ }^{4}$ consagra, desde 0

\section{Em suas célebres Relectio de Indis, de 1539.}

2. Cf. Juan Antonio Carillo Salcedo, El Derecho Internacional en Perspectiva Histórica, Madrid, Tecnos, 1991; especificamente em relação aos direitos territoriais dos índios, da Colônia à República, veja-se Manuela Carneiro da Cunha, "Terra indigena: história da doutrina e da legislaçāo", in Os Direitos dos Indios. Ensaios e Documentos, São Paulo, Brasiliense, 1987, pp. 53-101.

3. O reconhecimento dos direitos dos indígenas americanos estava ligado a indagações teológicas acerca da relação entre direitos e credo. Tratava-se, inicialmente, de determinar se não-cristãos podiam ser sujeitos de direitos. Porém, ainda que se determinasse que do simples fato de não ser cristão, no caso dos gentios, não decorria a perda de direitos naturais, restava a determinar se a prática de pecados mortais (como a antropofagia, por exemplo) podia privar os gentios de seus direilos. Os mais respeitados dentre os teólogos-juristas. afirmavam que nem mesmo nesses casos podiam os gentios ser legitimamente privados de seus direitos.

4. Essa legislação, constituída por centenas de leis, cartas e ordens provenientes da Metrópole e da administração colonial, complementava as leis codificadas de Porlugal - Ordenações do Reino - a que estava sujeita também a Colônia, tratando especificamente de questões que só surgiam aqui. Nem é preciso dizer que grande parte da legislação para a Colônia refere-se a questões econômicas (direitos de comércio, impostos, etc.). Outra parte considerável, que aqui consideramos, refere-se à entāo chamada "questāo indigena" Tratei de modo mais geral dos princípios da legislação indigenista no período colonial em "Indios Livres e Indios Escravos: os princípios da legislação indigenista do 
século XVI, os direitos dos povos indigenas a seus territórios. Em Alvará de 1596, referindo-se às terras dos índios nos aldeamentos localizados junto às povoações coloniais, lê-se: "o gentio [...] será senhor de sua fazenda, asi como o he na serra" Sob a formulação "senhores de suas terras nas aldeias como o são na serra" reconhecimento cristalino de direitos territoriais anteriores à colonização e, independentes dela, a afirmação seria retomada nas Leis de 1609 e 1611, ${ }^{6}$ que constituem marcos na legislação indigenista colonial, e, com algumas variações, em vários documentos legais posteriores. Reconhecidos os direitos legais e históricos, como diriamos hoje, dos povos indígenas às suas terras, durante toda a colonização não houve um momento sequer em que esse princípio fosse expressamente negado ou restrito.

Quando se analisa mais detalhadamente o corpo de princípios legais que norteavam a política indigenista, e se acompanha a prática dessa política, verifica-se que, na verdade, os povos indígenas brasileiros acabaram sendo despossuídos de suas terras. As análises dos documentos legais relativos a índios do período colonial em geral se ressentem do fato de considerar alguns documentos isoladamente e de retirar de seus contextos trechos de documentos legais. Os documentos que afirmam direitos territoriais, estabelecem punições para colonos invasores de terras indígenas e ordenam a demarcação de terras de índios são numerosos. É preciso considerá-los em conjunto e referi-los ao sistema jurídico em que se inserem se se quiserem entender os princípios, e é igualmente preciso ver de que modo as determinações legais são incorporadas na prática, se se quiserem entender os fatos. O objetivo deste artigo é apontar para algumas das questões que sugere a análise dos textos legais relativos aos índios no período colonial, no tocante aos direitos territoriais indígenas.

período colonial (sécs. XVI a XVIII)", in Manuela Carneiro da Cunha (org.), História dos Indios no Brasil, São Paulo, Cia. das Letras, 1992, pp. 115-132.

5. "Alvará e Regimento sobre a Liberdade dos Índios", 26.07.1596. In Serafim Leite, S.J. História da Companhia de Jesus no Brasil, Lisboa/Rio de Janeiro, Portugália/Civ.Brasileira, 1938-50, v. 2, pp. 623-624. Neste, bem como nos demais trechos de documentos legais citados, mantenho a grafia que se encontra na fonte utilizada.

6. Lei de 30.07.1609, "Em que se determina que por ser contra o Direito Natural o cativciro não se podem cativar os gentios do Brasil" e Lei de 10.09.1611, "Sobre a liberdade do gentio da terra e da gucra que se the pode fazer" In Anais do Arquivo Público da Bahia, v. 29, 1943, pp. 24-29 e 8-15, respectivamente. 
Vejamos, por exemplo, a expressão "senhores de suas terras nas aldeias como o são na serra" Se, por um lado, reconhece inegavelmente direitos territoriais dos índios, no que se conforma aos princípios legais correntes, insere-se em documentos que não tratam dessas terras que lhes pertencem "na serra" das quais são "senhores" mas de terras de aldeamentos, que lhes são doadas, em sesmaria, pela Coroa portuguesa. Relembremos brevemente as balizas da política indigenista colonial. O projeto da Coroa portuguesa, no tocante aos índios, seguia idealmente o seguinte itinerário: em primeiro lugar, era preciso convencê-los, pacificamente, a "descerem" do interior (a "serra" ou "sertão") para a costa; lá, junto aos portugueses, os índios pacificamente descidos seriam aldeados, sob a administração (inicialmente) de missionários; os índios das aldeias constituiriam a reserva de mão-de-obra da Colônia (serviços obrigatórios para a Coroa e remunerados para particulares), enquanto seriam convertidos, educados, "civilizados"; até que, finalmente, desaparecessem enquanto gentios e passassem a engrossar a população de vassalos da Coroa portuguesa na Colônia. Isso é o que se depreende dos numerosos documentos que tratam dos principios legais de descimentos, aldeamentos, administração de mão-de-obra das aldeias, salários, etc. ${ }^{7}$

Pois bem, quando os índios "descem" para os aldeamentos, ${ }^{8}$ suas terras, aquelas que lhes pertenciam, são abandonadas. Tornam-se terras sem dono, e assim revertem, legalmente, para a Coroa, na condição de terras devolutas. As terras que se lhes oferece em troca, das quais seriam "senhores nas aldeias [da costa]" são igualmente terras devolutas, que por isso mesmo podem ser dadas, pela Coroa, em sesmaria.

Os documentos são consistentes na defesa do argumento principal para a concessão de terras aos índios em sesmaria: é de salvação de almas que se trata. Para que as almas dos índios possam ser salvas, é preciso que eles se aproximem das povoações portuguesas, passando a viver nos aldeamentos, e que neles possam garantir o seu sustento através da lavoura. Nada disso é possivel, reconhecem os

7. Para uma indexação dos documentos legais referentes aos indios no período colonial, remeto a B. Perrone-Moisés, "Inventário da Legislação Indigenista 1500-1800" (Anexo 2) in Manucla Carneiro da Cunha (org.), História dos Indios no Brasil, São Paulo. Cia. das Letras, 1992, pp. 529-566.

8. Utilizo aqui o termo "aldeamento" em relação às aldeias de índios localizadas junto às povoações coloniais, por determinação das autoridades metropolitanas e/ou coloniais, para distinguilas das aldeias indigenas propriamente ditas, aquelas que habitavam na "serra", cujas terras lhes pertenciam. 


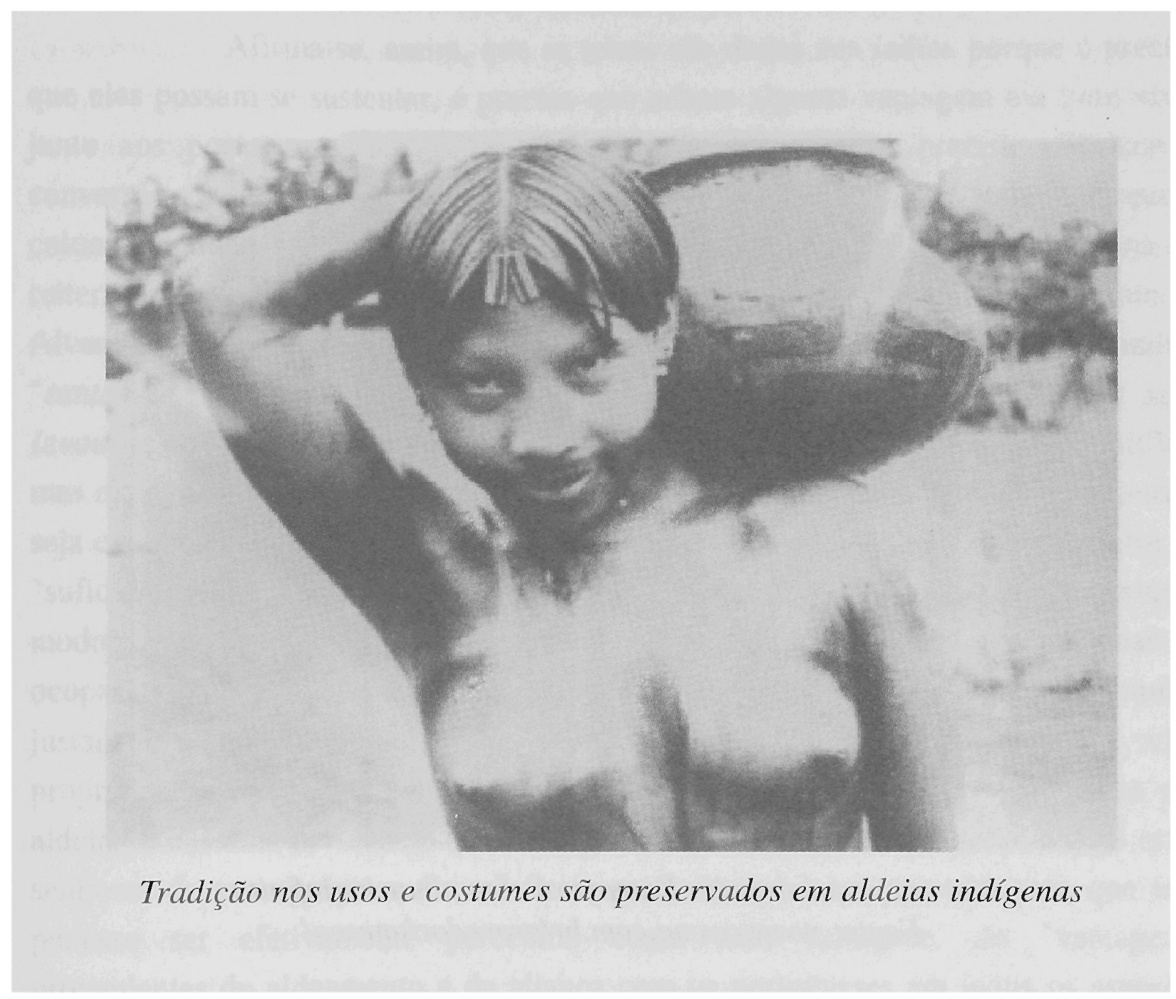




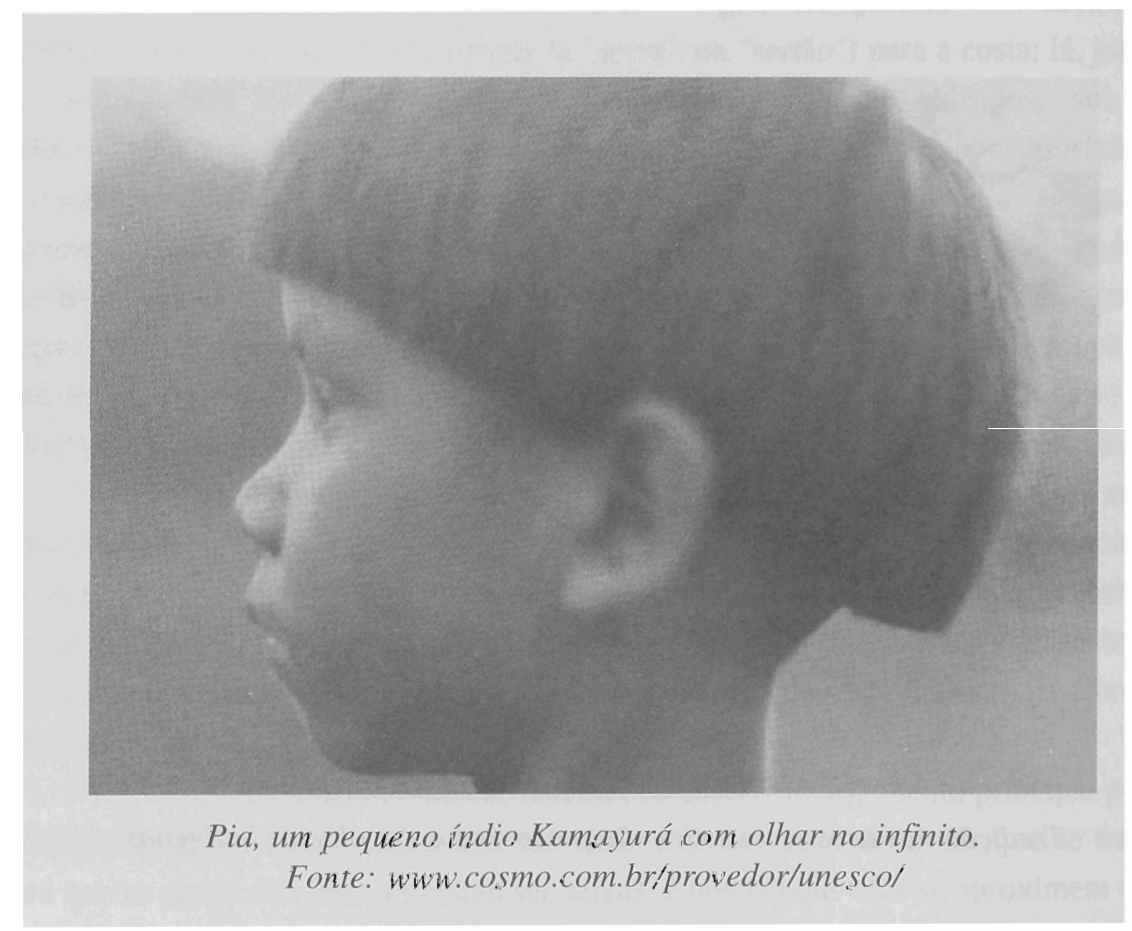


textos legais, sem terras. No Alvará-Régio de 21.08.1587 encontra-se uma das expressões mais claras dessas justificativas: "Eu el Rey faço saber aos que este Alvará virem que eu sou informado que será muito serviço de deos e meu e em prol e beneficio das fazendas e engenhos de meus vassalos das partes do brazil darem se terras de sesmaria ao gentio que decer do sertão pera faserem suas lavouras, e que sera isto meio pera decerem muitos e virem mais depressa no conhecimento de nossa santa fee e receberem o santo batismo, [...]" 9

Afirma-se, assim, que as terras são dadas aos índios porque é preciso que eles possam se sustentar, é preciso que achem alguma vantagem em irem viver junto aos portugueses e em se converterem, em suma, é preciso viabilizar a conversão, esse pilar da colonização, justificativa primeira de toda a empresa colonial. Cada aspecto desse argumento merece comentário: afirma-se, reiteradamente, que é preciso dar aos índios terras suficientes para o seu sustento. $\mathrm{O}$ Alvará-Régio de 1587, mencionado acima, ordena que sejam dadas aos índios "tantas terras de sesmaria quantas bastarem pera comodamente faserem suas lavouras e se manterem" Até o final do período colonial, a formulação se modifica, mas mantém-se a idéia de que aos índios devem ser concedidas terras cuja extensão seja compatível com suas necessidades de sobrevivência. Estabelece-se o critério da "suficiência" sem contudo especificar de que modo se há de calculá-la; de qualquer modo, pode-se supor que o cálculo não fosse feito segundo critérios indígenas de ocupação da terra, mesmo porque o projeto de civilização dos índios supunha, justamente, que estes abandonassem quaisquer valores e modos de vida propriamente indígenas. Já o argumento da "vantagem" de se possuir terras nas aldeias é bastante revelador: que vantagem seria essa, posto que os índios já eram senhores de suas próprias terras? Seria preciso supô-los sem-terras para que isso pudesse ser efetivamente percebido como uma vantagem. As "vantagens" provenientes do aldeamento e da aliança com os portugueses em todos os aspectos costumam apresentar esse aspecto, para nós, irônico: na melhor das hipóteses, os índios ganhariam o que sempre tiveram - sua liberdade, suas terras. Com o olhar distanciado do presente, já não vemos vantagem alguma em perder a liberdade de viver segundo os moldes da própria cultura. E um olhar atento revela a perda das

9. Alvará-Régio de 21.08.1587, "Para que aos indios que descem do sertão se dessem terras para suas aldeias junto às fazendas e sesmarias para suas lavouras" in Documentos para a História do Açucar, v. I Legislação. Rio de Janeiro. Instituto do Açúcar e do Álcool, Serviço Especial de Documentação Histórica, 1954, pp. 321-322. 
terras... Na época em que tais documentos foram redigidos, contudo, a conversão era o valor supremo, e a vantagem de ser cristão, indiscutível.

Em alguns documentos, partindo da mesma justificativa, a catequese, ocorre um deslocamento: neles não se afirma que as terras são dadas aos índios para que se convertam, mas sim que terras só podem ser dadas aos índios já convertidos, de modo que isso sirva de incentivo à conversão dos pagãos. É o que afirma claramente o Regimento do governador geral do Brasil, Francisco Geraldes, em 1588, quando ordena dar terras aos índios "que se fizerem cristãos" e "pera que os que inda o não forem folguem de o ser favorecereis os que já tiverem recebido agoa do santo baptismo para com iso eńtenderem que em se tornarem cristãos não tão sómente fazem o que convem á salvação de suas almas mas ainda a seu remedio temporal' ${ }^{10}$ Pouco antes disso, em meados do século XVI, a regente D. Catarina, em carta ao governador Mem de Sá, sugeria, apoiada na argumentação dos missionários jesuítas, que "seria grande remédio para aumento e conservação dos ditos gentios repartirem-se e darem-se aos que fossem cristãos terras próprias e sítios e lugares para isso convenientes em que possam fazer os mantimentos..." 11

Embora o objetivo - a conversão dos gentios - se mantenha ao longo da colonização, o deslocamento é considerável do ponto de vista legal. Quando afirmam que só podem possuir terras em sesmaria os índios cristãos, as leis se conformam aos princípios que prevalecem para os colonos europeus, que também têm de ser cristãos para poderem receber sesmarias da Coroa. Por outro lado, não dar terras aos que não se converterem - para que queiram se converter - significa não-reconhecer nenhum direito "natural" dos índios às terras. Isso é o oposto do que se encontra expresso no já mencionado Alvará de 1596, quando afirma que o gentio - isto é, os índios não-cristãos - é "senhor de suas terras"

A leitura de alguns documentos de doação de sesmarias aos índios é reveladora das formas de (des)considerar os direitos indígenas a seus territórios. $\mathrm{O}$ que poderíamos chamar de direitos históricos dos índios às suas terras, quando mencionados, costumam aparecer no requerimento por eles enviado, através de seu procurador, à Coroa, mas não nos termos da concessão. Assim, uma carta de

10. "Regimento do Governador Geral do Brasil", de 08.03.1588, § 5. In Documentos para a História do Açúcar, v. 1, pp. 355-376.

11. Citado em G. Thomas, Politica indigenista dos portugucses no Brasil, 1500-1640", São Paulo, Loyola, 1982, p. 125. 
sesmaria de 1580 , por exemplo, refere-se a uma petição enviada ao governador da Capitania de São Vicente em nome dos índios de duas aldeias do planalto de Piratininga, para que lhes fossem dadas terras em sesmaria, por serem "elles supplicantes naturaes das mesmas terras' e precisarem delas para poderem se manter, e serem doutrinados na fé. A sesmaria é concedida "aos taes indios e vendo sua petição e as razões que nella allegam serem justas e outrosim a maior parte delles serem christãos e terem suas igrejas estarem sempre prestes para ajudarem a defender a terra e a sustental-a o que fizeram assim em meu tempo como dos capitães passados pela informação que disso tenho e ser-Ihe necessario terras $e$ façam seus mantimentos para sua sustentação e visto como cada dia vem mais gentio para as ditas aldeias o que tudo é proveito e bem da republica" ${ }^{12}$ Ou seja, as razões alegadas são reconhecidas como justas, mas mais importantes são outras considerações: o fato de serem cristãos, a defesa e o sustento da Colônia, o interesse no aumento da população indígena aldeada... Várias sesmarias de terras de aldeamentos são concedidas, não aos índios, mas ao missionário encarregado de sua administração e, de modo geral, os "direitos naturais" dos índios às terras sequer são mencionados.

Existem, contudo, raros momentos em que a legislação menciona expressamente o Direito Natural dos índios às suas terras, a que a expressão consagrada "senhores de suas terras... remetia. É o caso da Provisão-Régia de $1^{\circ}$ de abril de 1680 para o Estado do Maranhão, na qual se lê: "E para que os ditos Gentios que assim decerem e os mais que ha deprezente milhor se conservem nas Aldeas, Hei por bem que sejão senhores das suas fasendas como o são no Certão sem lhes poderem ser tomadas nem sobre elles se lhes fazer molestias (...) nem serão obrigados a pagar foro ou tributo algum das ditas terras, ainda que estejão dadas em sesmaria a pessoas particulares por que na concessão destas se reservaria sempre o prejuiso de terceiro, e muito mais se entende e quero se entenda ser reservado o prejuiso e direito dos Indios primarios e naturaes Senhores dellas" (grifo meu). ${ }^{13}$ O Diretório pombalino de 1757 , no mesmo sentido, manda garantir as terras de lavoura aos Indios, que na conformidade das Reaes Ordens [...] são os

12. "Traslado de carta de data de sesmaria das terras dos índios" 31.10 .1580 . Registro Geral da Câmara Municipal de São Paulo, v. 1, 1917, pp. 354-357.

13. "Lei sobre a liberdade do gentio do Maranhão". in Anais da Biblioteca Nacional, v. 66, Rio de Janeiro, 1948, pp. 57-59. 
primarios, e naturaes senhores das mesmas terras" (grifo meu). ${ }^{14}$

Toda essa legislação diz respeito àqueles que "aceitam" o descimento e o aldeamento. Mas, enquanto isso, há povos que resistem à colonização, atacam os estabelecimentos portugueses e os europeus que se aventurarem em seus territórios. Os direitos destes às terras que ocupam existem, pode-se deduzir, tanto quanto os daqueles que foram aldeados; eram esses os direitos claramente estabelecidos já na obra de Francisco Vitória. Aos povos que resistem, contudo, aplica-se o princípio da guerra justa. Debatida em conjunto com outros princípios durante o século XVI, por haver dúvida quanto à Justiça de aplicá-la a povos que não eram infiéis, a definição de guerra justa é um tema vasto. ${ }^{15}$ Resumiremos seus pontos principais: aos índios do Brasil, a guerra justa se aplica fundamentada basicamente em dois pontos reconhecidos pela doutrina tradicional: a prática de atos hostis contra vassalos da Coroa portuguesa e o impedimento da pregação do Evangelho. Assim, foram vítimas de guerra justa vários povos que reagiram à colonização, assim como outros, transformados pelo discurso dos colonizadores em inimigos bárbaros para convencer a Coroa da Justiça de se Ihes aplicar tal princípio. Se a guerra justa era o principal caso legalmente reconhecido de escravização, naquilo que aqui nos interessa mais de perto, ela tinha uma conseqüência legal importante: as terras dos povos vencidos revertiam para os vencedores.

Os povos indígenas que "descem" perdem, portanto, legalmente, os direitos sobre as terras que ocupavam anteriormente, ao deixarem-nas, e passam a viver em terras a eles cedidas pela Coroa nos aldeamentos. Já os povos vencidos em guerra perdem o direito às suas terras, juntamente com a sua liberdade. Os princípios legais são mantidos, os direitos dos índios às suas terras não são negados, mas o resultado prático é a expansão das terras da Coroa. Cabe lembrar que, nos séculos anteriores, a Coroa portuguesa já tinha obtido um amplo controle das terras de Portugal apropriando-se de terras da nobreza, sem jamais negar os direitos dos nobres a elas. ${ }^{16}$ Os princípios expressos nas leis são, de fato, constantemente

14. "Diretório que se deve observar nas povoações dos indios do Pará e Maranhão" 1757. § 80. In Leda M. C. Naud, "Documentos sobre o Índio Brasileiro", Revista de Informação Legislativa, ano 8. n. 29, jan-mar, 1971, pp. 263-279.

15. Remeto, para uma análise mais delalhada da discussão acerca da guerra justa a meu artigo "A Guerra Justa em Porlugal no Séc. XVI" in Revisla da Sociedade Brasileira de Pesquisa Hislórica n. 5, São Paulo, 1990, pp. 5-10.

16. No processo de centralização monárquica, a Coroa procurou, como observa Sérgio Buarque de 
desrespeitados. Os documentos legais deixam claro que as terras de sesmarias dos índios não podem ser ocupadas por outrem, e estebelecem, em caso de ocupação ilegal, sua restituição imediata. No Alvará de 1596 (documento exemplar quanto à política de terras, o que justifica sua presença reiterada nesta reflexão) por exemplo, lê-se " as ditas terras Ihe [ao gentio que desceu para aldear-se] pertencem, e lhe não poderem ser tomadas em tempo algum --- e outro sy ey por bem que as terras que forem dadas de sesmaria a algumas aldeias dos indios que estão junto da capitania do salvador das ditas partes as tenhão e possuão, e sendo-Ihe tomadas alguas por meus vasallos, o dito meu guovernador ou provedor de minha fazenda Ihos fará logo restituir em effeito, procedendo nisso com muyta deligencia" Numerosos outros exemplos poderiam ser mencionados, que deixam clara a extensão da ocupação ilegal de terras das aldeias dos índios por parte de colonos. ${ }^{17}$

Mas, para além do flagrante desrespeito, que as autoridades coloniais tentam evitar por meio de punições claramente estabelecidas pela legislação concebida na Metrópole, o movimento de expansão territorial é inerente à colonização. Desde o século XVI, lembrávamos no início desta reflexão, eram postos em causa os direitos europeus de conquista. As leis jamais negaram que os índios fossem livres, e que, sendo livres, tivessem direitos sobre seus bens. A

Holanda (História Geral da Civilização Brasileira. Tomo I. A Época Colonial. São Paulo, DIFEL, 1985, 2 vs.), diminuir os poderes dos nobres, estendendo a jurisdição real a todas as terras do reino. D. Duarte tem, nesse sentido, uma política clara de recuperaçāo das terras para a Coroa (op. cit, v. 1, p. 15). D. João I, nas palavras de S. Buarque de Holanda, "fora impelido a fazer grandes concessões de terras aos nobres, por ocasião da luta contra Castela, e ele mesmo tivera a oportunidade de medir os perigos dessas doações para o prestigio do poder central. Daí os seus esforços no sentido de chamar para a Coroa o exercício da jurisdição nas terras dos fidalgos, cabendo-Ihe imaginar, ter em mente, a lei baixada pelo seu sucessor D. Duarte e, que, por isso, ficou conhecida como lei mental. Proibindo a alienação dos bens de raiz e dos direitos da Coroa que tivessem sido doadas perpetuamente, admitindo, por outro lado, somente o filho varão e primogênito à sucessão de tais bens, objetivava-se facilitar a reversão, para o monarca, das terras doadas aos nobres" (idem, p. 19).

17. Assim a Provisão de 08.07.1604, que ordena que os que roçam terras dos índios forros das aldeias de Piratininga "as larguem logo e deixem livres e desembargadas e sem impedimento para que os ditos indios as cultivem sem a isso thes ser posto nenhuma duvida" (in Registro Geral da Câmara Municipal de São Paulo, v. 1, 1917, pp. 356-359); a Carta-Régia de 17.01 .1691 que determina que sesmeiros não se façam "senhores das Aldeias que nellas [sesmarias] houver dos Indios, nem das terras que têm para seu sustento" (in Documentos Interessantes para a História e costumes de São Paulo, Arquivo Municipal de São Paulo, v. 3, pp. 80-81); a Direção de 18.05 .1759 para as vilas de índios da "Capitania de Pernambuco e suas anexas", que afirma, em seu $\$ 86$ que os brancos que vierem a residir nas aldeias "de nenhum modo poderão possuir as terras, que na forma das reaes ordens de Sua Majestade se acharem distribuidas pelos indios" (in Rev. do Inst. Histórico e Geográfico Brasileiro, Rio de Janeiro, v. 46, pp. 121-171). 
colonização, ao avançar, foi produzindo, por assim dizer, "terras devolutas" quando promovia o abandono das terras indígenas por seus "senhores primários, e naturais" por meios pacíficos ou violentos. O resultado, favorável à Coroa, e à colonização, foi, para os índios, a perda de suas terras.

São Paulo, outubro de 1999.

Bibliografia

BEOZZO, José Oscar. Leis e Regimentos das Missões. Política Indigenista no Brasil. São Paulo, Loyola, 1983.

BOXER, Charles R. O Império Colonial Português (1415-1825). Lisboa, Ed. 70, 1981.

BUARQUE DE HOLANDA, Sérgio. História Geral da Civilização Brasileira. Tomo I. A Época Colonial. São Paulo, DIFEL, 1985, 2 vs.

CARNEIRO DA CUNHA, Manuela. Os Direitos dos Indios. Ensaios e Documentos. São Paulo, Brasiliense, 1987.

DIAS, J. S. da Silva. Os Descobrimentos e a Problemática Cultural do Séc. XVI. Lisboa, Presença, 1982.

LEITE, Serafim S. J. História da Companhia de Jesus no Brasil, Lisboa/Rio de Janeiro, Portugália/Civ.Brasileira, 1938-50, 10 vs.

MENDES JR., João. Os Indigenas do Brasil, Seus Direitos Individuaes e Politicos. São Paulo, Hennies Irmãos, 1912.

OTÁVIO, Rodrigo. Os Selvagens Americanos Perante o Direito. São Paulo, Cia. Ed. Nacional, 1946 (Col. Brasiliana n. 254).

PERRONE-MOISÉS, Beatriz. A Guerra Justa em Portugal no Séc. XVI" Revista da Sociedade Brasileira de Pesquisa Histórica n. 5, São Paulo, 1990, pp. 5-10.

"Índios Livres e Índios Escravos: os princípios da legislação indigenista do período colonial (sécs. XVI a XVIII)" in Manuela Carneiro da Cunha (org.), História dos Índios no Brasil, São Paulo, Cia. das Letras, 1992, pp. 115-132.

SALCEDO, Juan Antonio Carillo. El Derecho Internacional en Perspectiva Histórica. Madrid, Tecnos, 1991.

THOMAS, Georg. Política indigenista dos portugueses no Brasil, 1500-1640, São Paulo, Loyola, 1982.

VITORIA, Francisco de. Relecciones sobre los Indios y el Derecho de Guerra. Buenos Aires/México, Austral, 1947 (1539). 


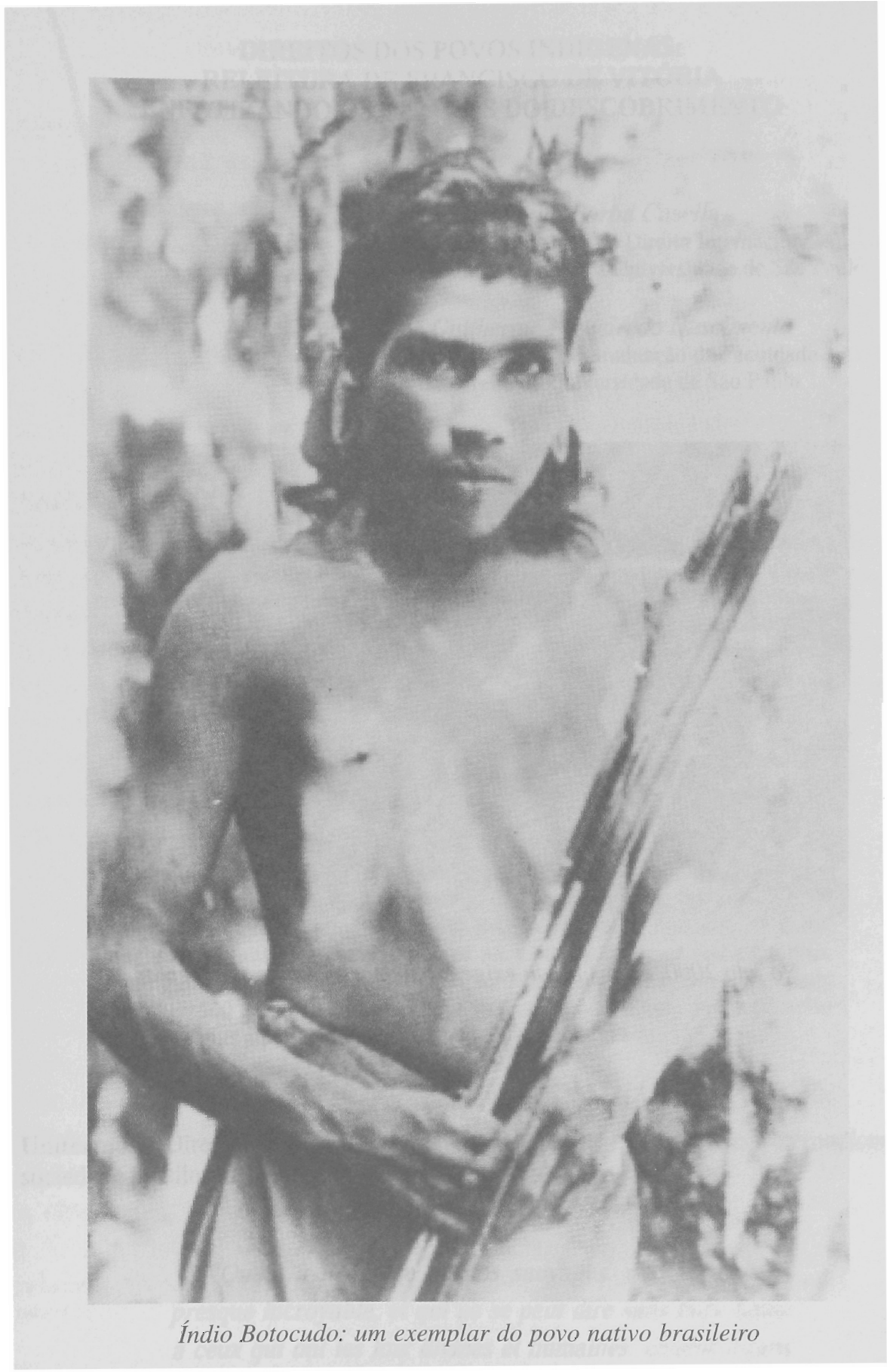




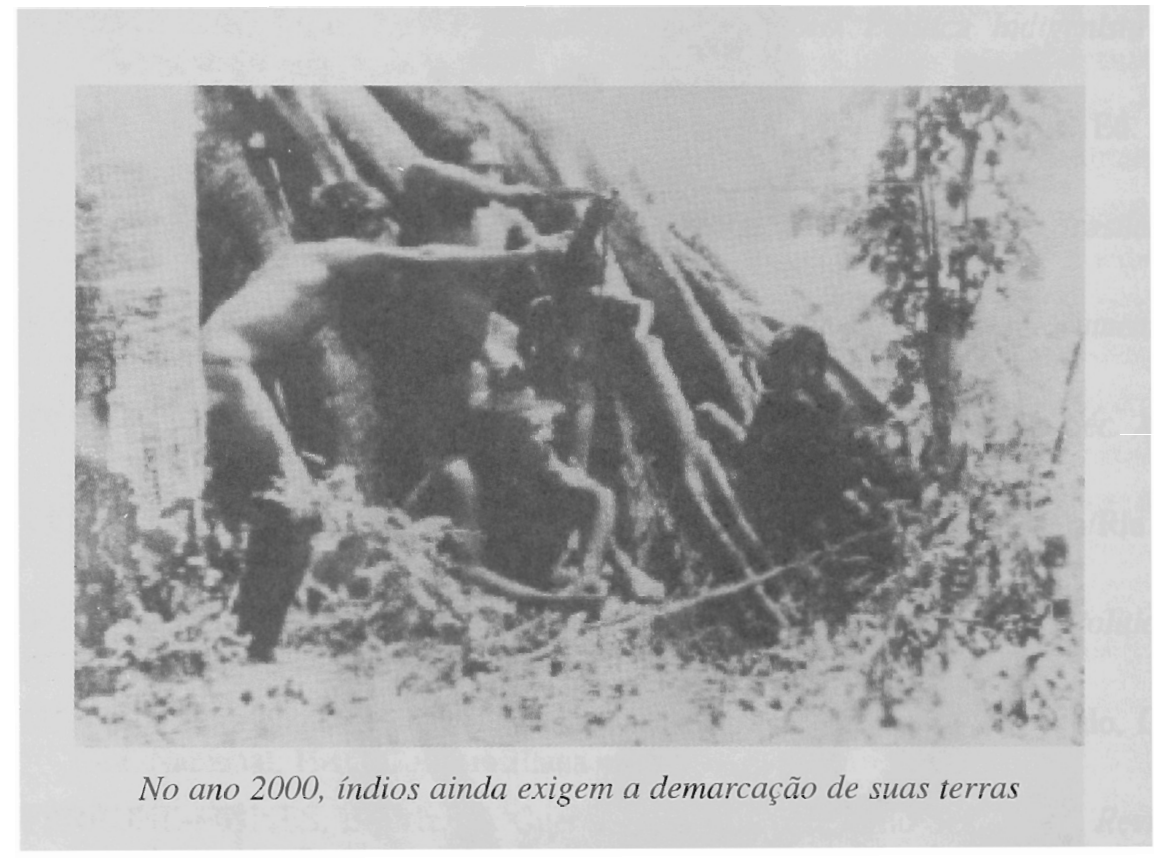

